\title{
THE EFFECT ON THE MOUSE ADRENAL X-ZONE OF BLASTOCYSTS TRANSPLANTED UNDER THE KIDNEY CAPSULE
}

\author{
P. V. HOLMES AND A. D. DICKSON \\ Division of Morphological Science, Faculty of Medicine, \\ The University of Calgary, Calgary 44, Alberta
}

(Received 15th September 1970)

\begin{abstract}
Summary. A secretion from mouse trophoblast was investigated using the mouse adrenal $\mathrm{X}$-zone, which degenerates differently under the influence of androgens and progestagens. Blastocysts were transplanted under the kidney capsules of female mice and, subsequently, the kidneys and adrenals were examined histologically for trophoblast growth and $\mathrm{X}$-zone degeneration, respectively. Adrenal X-zone degeneration was evident in immature mice only when they received blastocyst transplants, correlating trophoblast proliferation with $\mathrm{X}$-zone degeneration. The degeneration found in both transplanted and control adults correlates maturity with $\mathrm{X}$-zone regression. The fact that the mode of degeneration was always histologically similar to that induced by progestagens implies a progestagenic mediation.
\end{abstract}

It has been demonstrated recently by Holmes \& Dickson (1971) that progesterone and testosterone induce morphologically distinct forms of regression of the $\mathrm{X}$-zone of the mouse adrenal cortex. They also showed that X-zone degeneration begins in the female at puberty, is completed rapidly in first pregnancy and is histologically similar to that induced by progesterone injections.

Kirby (1966) transplanted blastocysts into adult mice and observed X-zone regression in intact and ovariectomized females. Jones (1951) also transplanted blastocysts into adult mice, but noted that X-zone degeneration occurred only when mature ovaries with corpora lutea were present. The present work was designed to confirm or refute any correlation between trophoblast tissue secretions and adrenal $\mathrm{X}$-zone degeneration.

Swiss Webster albino mice were used and were maintained as described previously (Holmes \& Dickson, 1971). Fertilized ova were flushed with Hanks' physiological saline from the uterine horns of young primigravid females at $3 \frac{1}{2}$ days post coitum. The blastocysts were manipulated singly using a saline-filled system composed of a micrometer syringe, tubing and a bevel-ended micropipette. One blastocyst was transplanted under each kidney capsule of 172 immature and forty adult female mice under sodium pentobarbital anaesthesia. One hundred control mice underwent identical surgical procedures, except that no blastocyst was present in the Hanks' solution injected under the 
kidney capsule. The mice were killed by cervical dislocation 11 days after transplantation and the adrenal glands and kidneys were collected, embedded in paraffin wax and serially sectioned for histological examination. Table 1 outlines the operations and transplantations completed, the number of mice used, and the effect of the growing transplant on the adrenal X-zone.

TABLE 1

THE EFFECT ON THE MOUSE ADRENAL X-ZONE OF MOUSE BLASTOCYSTS TRANSPLANTED UNDER THE KIDNEY GAPSULE

\begin{tabular}{|c|c|c|c|c|c|c|}
\hline \multirow[b]{2}{*}{ Condition of mouse } & \multirow[b]{2}{*}{$\begin{array}{l}\text { No. of } \\
\text { mice } \\
\text { used }\end{array}$} & \multicolumn{2}{|c|}{$\begin{array}{c}\text { Trophoblast } \\
\text { growth present }\end{array}$} & \multicolumn{2}{|c|}{$\begin{array}{c}\text { Trophoblast } \\
\text { growth absent }\end{array}$} & \multirow[b]{2}{*}{$\begin{array}{l}\text { No. of } \\
\text { mice } \\
\text { died }\end{array}$} \\
\hline & & $\begin{array}{l}\text { Total } \\
\text { no. }\end{array}$ & $\begin{array}{l}\text { No. with } \\
\text { X-zone } \\
\text { degen. }\end{array}$ & $\begin{array}{l}\text { Total } \\
\text { no. }\end{array}$ & $\begin{array}{l}\text { No. with } \\
\text { X-zone } \\
\text { degen. }\end{array}$ & \\
\hline $\begin{array}{l}\text { 1. Intact immature transplanted } \\
\text { 2. Intact immature controls }\end{array}$ & $\begin{array}{l}57 \\
40\end{array}$ & 25 & 24 & $\begin{array}{l}30 \\
38\end{array}$ & $\begin{array}{l}2 \\
5\end{array}$ & $\begin{array}{l}2 \\
2\end{array}$ \\
\hline $\begin{array}{l}\text { 3. Ovariectomized immature } \\
\text { transplanted } \\
\text { 4. Ovariectomized immature controls }\end{array}$ & $\begin{array}{l}60 \\
20\end{array}$ & 22 & 22 & $\begin{array}{l}29 \\
20\end{array}$ & $\begin{array}{l}0 \\
0\end{array}$ & $\begin{array}{l}9 \\
0\end{array}$ \\
\hline $\begin{array}{l}\text { 5. Hysterosalpingo-ovariectomized } \\
\text { immature transplanted } \\
\text { 6. Hysterosalpingo-ovariectomized } \\
\text { immature controls }\end{array}$ & $\begin{array}{l}55 \\
20\end{array}$ & 20 & 17 & $\begin{array}{l}26 \\
18\end{array}$ & 1 & 9 \\
\hline $\begin{array}{l}\text { 7. Ovariectomized adult } \\
\text { transplanted } \\
\text { 8. Ovariectomized adult controls }\end{array}$ & $\begin{array}{l}40 \\
20\end{array}$ & 15 & 15 & $\begin{array}{l}24 \\
20\end{array}$ & $\begin{array}{l}15 \\
15\end{array}$ & $\begin{array}{l}1 \\
0\end{array}$ \\
\hline
\end{tabular}

Howard-Miller (1928) and Holmes \& Dickson (1971) have described the histological details of adrenal X-zone degeneration. The criteria of degeneration mentioned specifically by the latter investigators are: 1, peripheral $\mathrm{X}$-zone sharpening; 2, X-zone narrowing; 3, hyperaemia; 4, cytoplasmic shrinkage; 5 , nuclear pycnosis; 6 , loss of cytoplasmic staining; 7 , fibre-layer concentration; and 8 , fatty degeneration. In the present work, the X-zone degeneration observed in all cases was histologically similar to that induced by progesterone, the principal characteristics of which are fatty degeneration and fibre-layer concentration. Fatty degeneration is not observed in testosterone-induced $\mathrm{X}$-zone

\section{EXPLANATION OF PLATE 1}

FIG. 1. Adrenal gland section, as seen in immature female mice, whether intact, ovariectomized or hysterosalpingo-ovariectomized, 11 days after transplantation of a $3 \frac{1}{2}$-day-old blastocyst under each kidney capsule. Note the narrow $\mathrm{X}$-zone, the fatty degeneration and the disorganized proliferating zona fasciculata cells. $\times 158$.

Fig. 2. Adrenal gland section from an intact immature female control mouse. Note the wide band of densely staining X-zone cells. $\times 158$.

Fig. 3. Adrenal gland section as seen in all adult mice 11 days after transplantation of a $3 \frac{1}{2}$-day-old blastocyst under each kidney capsule. Note the narrow, fibrous X-zone with fatty degeneration. $\times 158$.

Fic. 4. Adrenal gland section as seen in immature mice treated with testosterone propionate. Note the nuclear pycnosis, loss of cytoplasmic staining and lack of fatty degeneration. $\times 200$. (Holmes \& Dickson, 1971.) 
PI. IIY:
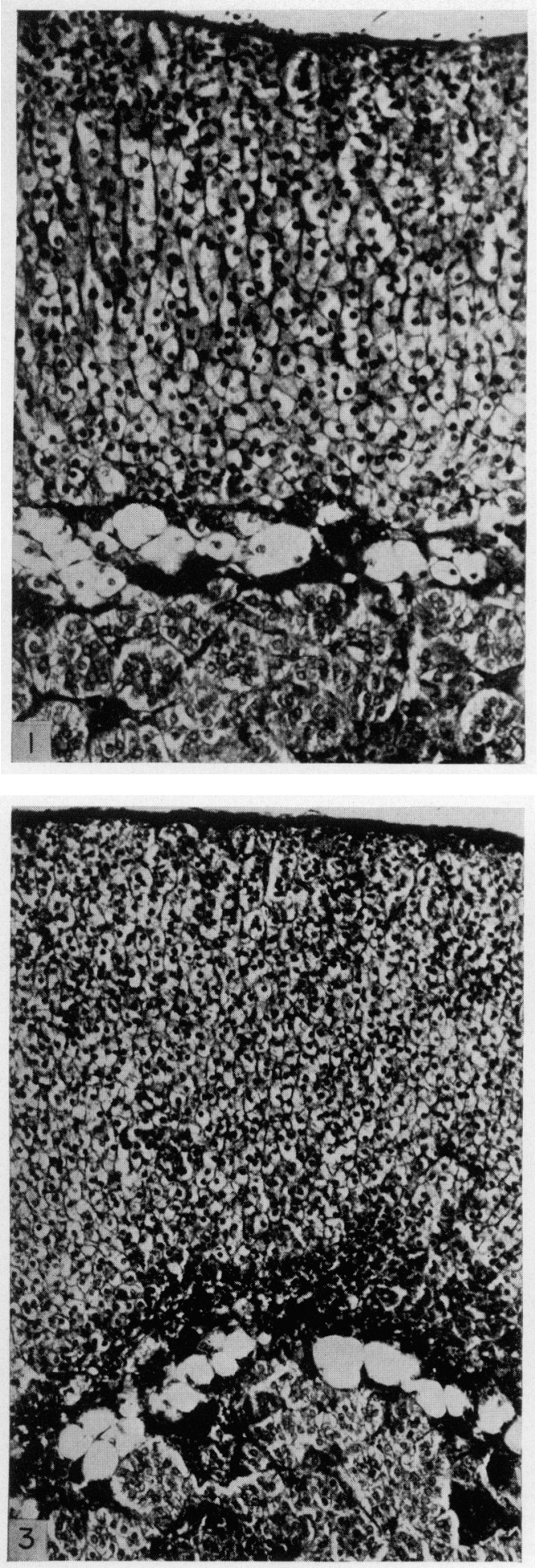
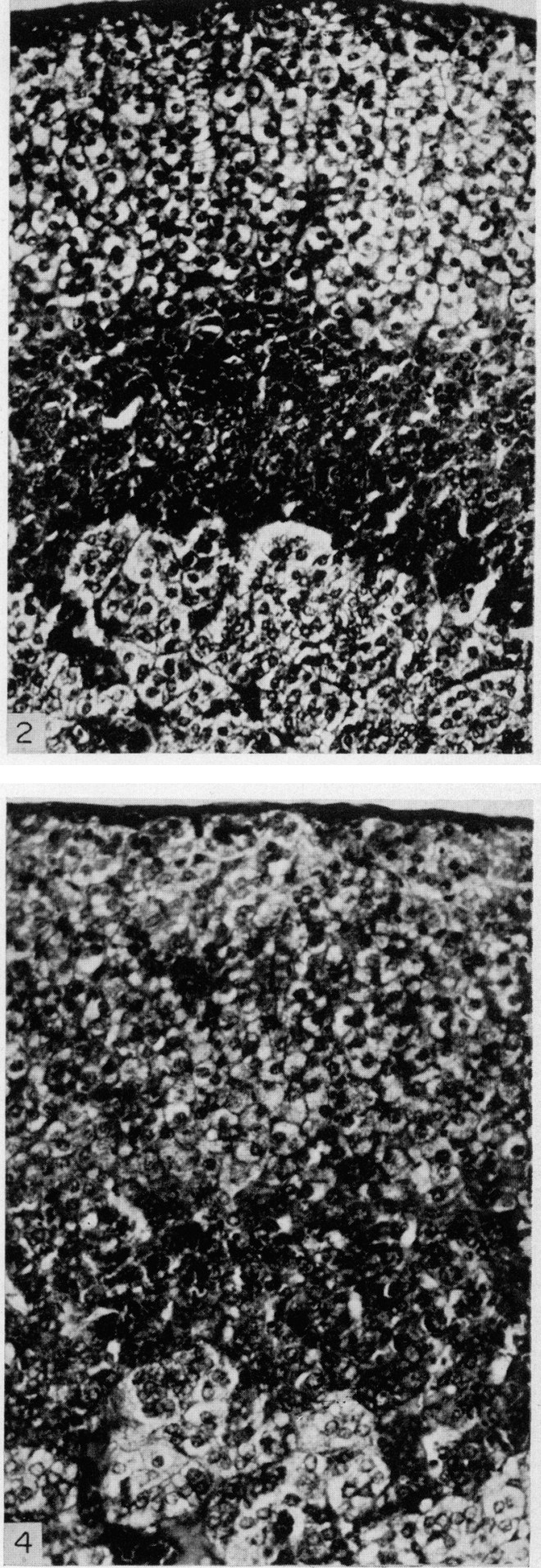
degeneration, which principally involves nuclear pycnosis, loss of cytoplasmic staining and cytoplasmic shrinkage (Pl. 1, Fig. 4).

Comparison of the numbers of successfully transplanted mice showing $\mathrm{X}$-zone degeneration (immatures 24/25, ovariectomized immatures 22/22, and hysterosalpingo-ovariectomized immatures $17 / 20)$ with their controls $(5 / 76)$ demonstrates a positive causal relationship between the presence of trophoblast tissue and adrenal $\mathrm{X}$-zone degeneration. The mode of degeneration is similar in all three immature experimental groups and is illustrated in P1. 1, Fig. 1. Lack of degeneration in the controls is illustrated in PI. 1, Fig. 2. In both the transplanted and control groups of adult females, the same mode of $\mathrm{X}$-zone degeneration was observed again (Table 1, lines 7 and 8; Pl. 1, Fig. 3), providing indirect evidence for cyclic progesterone secretions beginning with the inception of oestrous cycles. It is generally believed that progesterone is not secreted during the oestrous cycle in mice, contrary to findings in the rat (Constantinides, 1947).

Jones (1951) observed no X-zone degeneration in mature ovariectomized females, an observation not confirmed by the present work. Furthermore, Jones claimed that the degeneration he did observe was induced by secretions of androgen from blastocyst transplants to the kidney capsule and believed that his use of prostate grafts to the eye confirmed this. However, it has been shown that progesterone has considerable androgenic activity (Price, Mann \& LutwakMann, 1955). Although the claim by Jones (1951) that trophoblast cells secrete some androgen may be correct, their ability to secrete large quantities of progestagens would appear to correspond more closely to the findings. Kirby (1966) also used mature female mice in his work. As a result, any X-zone degeneration observed by him could have been induced by progesterone released during normal oestrous cycles. The number of control animals used by Kirby was insufficient to alert him to this probability.

This research was supported by the Medical Research Council of Canada, Grant No. MA-2808.

\section{REFERENGES}

Constantinmes, P. (1947) Progesterone secretion during the oestrous cycle of the unmated rat. 7. Endocr. 5, lxiv.

Holmes, P. V. \& Dickson, A. D. (1971) X-zone degeneration in the adrenal glands of adult and immature female mice. F. Anat. 108, 59.

Howard-Mirler, E. (1928) A transitory zone in the adrenal cortex which shows age and sex relationships. Am. F. Anat. 40, 251.

Jones, I. G. (1951) Endocrine effects in the virgin female host of fertilized mouse ova developing in extra-uterine sites. 7. Endocr. 7, 13.

KIRBY, D. R. S. (1966) The difference in response by the mouse adrenal X-zone to trophoblast derived from transplanted tubal eggs and uterine blastocysts. F. Endocr. 36, 85.

Price, D., Mann, T. \& Lutwak-Mann, C. (1955) The stimulating effect of female hormones on the metabolic activity and histological structure of male rat accessory reproductive glands. Anat. Rec. 122, 363. 